\title{
Review Article \\ Perspectives and Development of Electrical Systems in More Electric Aircraft
}

\author{
Ahmet Yigit Arabul $\mathbb{D}^{1},{ }^{1}$ Emre Kurt $\mathbb{D}^{D},{ }^{2}$ Fatma Keskin Arabul ${ }^{\mathbb{D}},{ }^{1}$ İbrahim Senol $\mathbb{D}^{\mathbb{D}},{ }^{1}$ \\ Martin Schrötter $\left(D,{ }^{3}\right.$ Róbert Bréda ${ }^{1}{ }^{3}$ and Dávid Megyesi ${ }^{3}{ }^{3}$ \\ ${ }^{1}$ Department of Electrical Engineering, Yildiz Technical University, Istanbul 34220, Turkey \\ ${ }^{2}$ Turkish Technic Inc., Istanbul 34912, Turkey \\ ${ }^{3}$ Department of Avionics, Technical University of Košice, Košice 04001, Slovakia
}

Correspondence should be addressed to Martin Schrötter; martin.schrotter@tuke.sk

Received 21 January 2021; Revised 12 April 2021; Accepted 16 April 2021; Published 29 April 2021

Academic Editor: Kan Xie

Copyright (c) 2021 Ahmet Yigit Arabul et al. This is an open access article distributed under the Creative Commons Attribution License, which permits unrestricted use, distribution, and reproduction in any medium, provided the original work is properly cited.

\begin{abstract}
On-board electrical systems are the key components of each modern aircraft. They enable its safer, more comfortable, and environmentally friendlier operation. The strict regulations to reduce pollution and noise are produced by aircraft eventuated in projects like Clean Sky or ICAO Global Coalition for Sustainable Aviation. One solution to environmentally friendlier operation is the full electric propulsion of the aircraft, which enables the reduction of both noise and pollution. Such a concept requires a total change of all on-board power systems and enables the profound change in aircraft design. This paper presents the evolution of aircraft power systems into the so-called more electric aircraft (MEA) and discusses the state-of-the-art electrical systems. Furthermore, the concept of all-electric aircraft (AEA) is presented here.
\end{abstract}

\section{Introduction}

Climate change is one of the biggest issues the world must currently face. The negative effects of the transportation sector on air pollution have been increasing over the years. Its share in global emissions is $24 \%$ and ranks second place after the energy sector with a share of $45 \%$ [1]. Therefore, many developed countries are currently supporting the use of electric vehicles and simultaneously restricting vehicles with combustion engines. In recent decades, the trend of aircraft electrification can be clearly seen in the replacement of the conventional power systems (hydraulic and pneumatic) with electrical system. This trend is known as More/All Electric Aircraft (M/AEA) power concept [2-5].

The electrical systems have advantages over conventional systems in lower maintenance cost/time, lower weight/volume, and higher efficiency, which positively affect fuel consumption [6, 7]. The concept of M/AEA has been investigated for a long time. In early days, the biggest issue was elec- trical actuator reliability, protection from electromagnetic interference (EMI) and lightning, and protection from embedded software errors [8-13].

In recent years, vast research on MEA electrical systems has been performed, especially on power generation, hybridelectric propulsion, power conversion, and power distribution. In the field of electric power generation, different types of integrated starter/generators $(S / G)$ have been investigated $[14,15]$. In the field of propulsion, various architectures have been proposed-all-electric $[16,17]$, where only electrical power is used for propulsion; hybrid electric [18], where both electrical power and combustion (fuel) power are used; and turboelectric [19-21], which is similar to hybrid propulsion concept without batteries. These new concepts enable, by implementing electric "traction" motors, a total change in aircraft design. In $[22,23]$, the distributed propulsion system with the utilization of boundary layer is investigated. The aim of these studies is to reduce the weight of the system, increase its efficiency, and reduce or eliminate the consumption of kerosene. 
The concept of AEA, with its electric propulsion for midsize and large-size aircraft, is not realistic today due to the limitations of electric power sources. For this reason, a combined/hybrid propulsion system, which uses at least two different power sources is proposed. This concept is known as Hybrid Electric Aircraft (HEA). The architecture of propulsion can be realized as a serial hybrid or parallel hybrid. Hybrid electric propulsion of ground vehicles was for the first time used at the end of the nineteenth century, and it has been again widely used in automotive from the beginning of the 21st century. However, hybrid propulsion is still under research in aviation. Many of the aircraft manufacturers and their suppliers are testing HEA concepts, e.g., Airbus E-Fan X [24], VoltAero Cassio 1 [25, 26], Zunum Aero ZA10 [27], ESAero ECO-150 [28], Diamond aircraft DA36 E-Star [29], and Ampaire EEL [30]. The biggest issue of HEA, besides the system's reliability, is the optimization of its power management-the balance of electrical and mechanical power [31-33]. The aim of HEA is to increase the fuel economy [34] and decrease the negative impact on the environment $[35,36]$.

MEA must generate a large amount of electrical power for many loads. To reduce the weight of the power distribution system, the ingenious system of electric power management has to be investigated. In $[37,38]$, the dimensioning of the electric power distribution system based on the actual power demand and priorities of individual loads is researched. A new type of decentralised distribution system/architecture is proposed $[39,40]$, in which the traditional circuit breakers are replaced by solid-state power controllers (SSPC), also known as electronic circuit breakers (ECB).

In the field of power conversion, small and efficient solidstate power converters (SSPCv) enable to implement the concept of the frequency wild AC system. The main idea of this concept is the elimination of the constant speed drive (CSD) or integrated drive generator (IDG), which positively affects the weight of the aircraft. In this concept, the generated frequency wild AC supplies resistive loads and regulated constant frequency AC supplies reactive loads [41]. In [42], the CSD/IDG is replaced by DC-Link, i.e., AC (variable)-DC-AC (constant) electrical power system converter.

Owing to the demand of very high energy density of electrical machines, the superconducting materials operating in normal temperature range are investigated [43-46].

In this paper, the electrical systems of current and future aircraft are presented. The authors try to point out on their advantages/disadvantages and perspectives for use on-board the aircraft. The paper is organized as follows: in Section 2, the history of aircraft electrical systems and the role of electricity for aircraft rapid expansion are discussed. Section 3 presents the evolution of the conventional aircraft power concept into the MEA and AEA and compares these concepts. Section 4 describes the areas in which electrical systems are/will be used in the MEA and AEA. Moreover, the advantages and shortcomings of these systems are presented here.

\section{History of Aircraft Electrical Systems}

Before the first heavier-than-air aircraft was constructed, hot-air balloons and later airships were used. At the begin- ning, the airships were powered by heavy and bulky steam engines, which required very long starting times, and later electric motors were used. The first electric flight is attributed to the Tissandier brothers with their "La France" airship in 1883 [47].

Although there had been several attempts before, the first successful flight of heavier-than-air aircraft was achieved by the Wright brothers in 1903 [48, 49]. This step represents the beginning of technological developments in the field of aviation. One of the first issues to be solved was the manoeuvrability of the aircraft. The 3-axis control system was designed and constructed by the Wright brothers [50]. Louis Bleriot designed the central stick and rudder pedals [51]. Later high-lift control surfaces (flaps) were proposed. The mechanical linkage was necessary to transfer the shift of the control stick and rudder pedals to the control surfaces. However, the pilot's effort to move the control surfaces rose linearly with their increasing size and quadratic with the increasing speed of the aircraft. The first power boosters had to emerge to help the pilot to operate the aircraft. As an example, in 1949, SNCASE S.E.2010 Armagnac used the classical mechanical linkage of control surfaces and hydraulic booster (Figure 1(a)). Later, in 1955, SNCASE S.E. 210 Caravelle used the first hydromechanical servo control, where power necessary to move the control surfaces was produced by hydraulic pumps (Figure 1(b)). Hydraulic pressure was provided by the engine-driven hydraulic pumps-central hydraulic system. In 1969, the Concorde used an analogue computer to assist the pilot in flight control. The second generation of electrical flight control came with Airbus A320 in 1984 (Figure 1(c)). It used a digital computer. In 2001, Airbus A340 proposed full-electric flight control with no mechanical back-up, however, the power to move the control surfaces was still produced and distributed in the same way as in SNCASE Caravelle in 1955. Finally, in 2001, Airbus A380 used electro-hydrostatic actuators (EHA), which used local hydraulic pumps powered by electric motors (Figure 1(d)).

An aircraft with four electrically driven propellers was proposed by A.N. Lodygin in 1914. The concept was designed in such a way that the combustion engines drove the generator which supplied electrical power to the motors [53]. Today, such a design is known as hybrid electric aircraft (HEA).

The first sources of electrical power on-board the aircraft were batteries, however, they had low power densities and very limited time of operation [54]. The first electrical systems required on-board the aircraft were the ignition systems and means for radio communication. Later, electric starter motors, external and internal lights, and electric heating were required. At this time, electricity was supplied mainly by small wind-driven DC generators located on the chassis and by rechargeable battery. Typical generated power was up to $250 \mathrm{~W}$ at $6 \mathrm{~V}$ and up to $500 \mathrm{~W}$ at $12 \mathrm{~V}$ in 1936 [53, 55]. Such generators were not powerful enough to drive starter motors, so engine-driven generators were introduced in 1934. Such a design decreased the drag of the aircraft and could even implement a retractable landing gear that even more improved the aerodynamic properties. The limitation of this concept was the increasing rotational speed of 


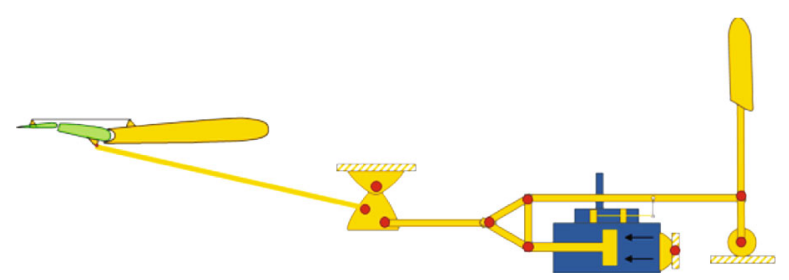

(a)

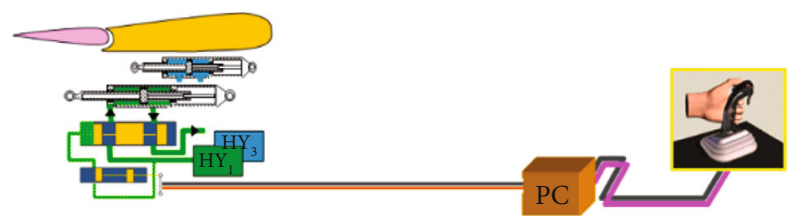

(c)

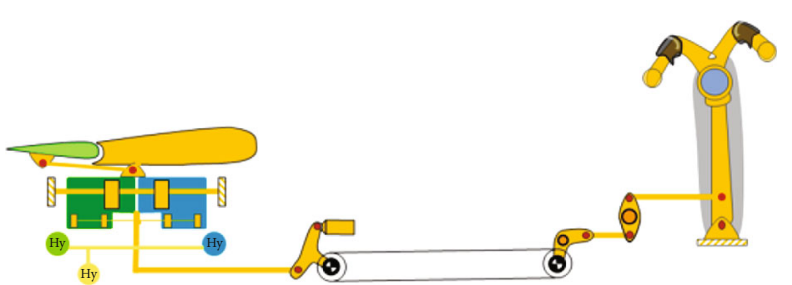

(b)

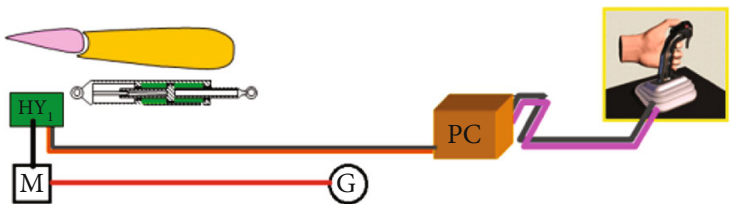

(d)

FIgure 1: Aircraft control system with (a) hydraulic booster, (b) hydromechanical servo control, (c) electrical flight control, (d) electrohydrostatic actuator. Adapted from [52].

new aircraft engines. New technologies for high-speed generators had to be developed. The typical power output of early engine-driven DC generators was up to $1 \mathrm{~kW}$ at $28 \mathrm{~V}$.

Different voltage levels of $\mathrm{AC}$ and $\mathrm{DC}$ power were required, so power converters (secondary sources of electrical power) had to be used (Figure 2(a)). To be implemented onboard the aircraft, they had to fulfill strict specifications like high power rate, low weight, and thermic values. The total power of loads consuming electric current on the highly electrified aircraft was about $5 \mathrm{~kW}$ in 1932. In 1940, it was six times more.

The first ground-to-air communication was provided by various visual aids, e.g., coloured paddles, signal flares, and hand signs. These methods were effective for ground crews; however, there was no way pilots could communicate back. The wireless telegraph system was used to send messages in Morse code. At first, it was from ground-to-air and later from air-to-ground. This system evolved fast into the first air-toground radio communication system in 1915 [56]. The problem of early radio communication technology was its operating distance which was smaller than the distance aircraft were able to travel. The required signal had to be carried over several airports to its recipient aircraft, which was a timeconsuming process. As the aircraft grew faster, they reached their destination before the message. The first air-to-air radio communication between aircraft was in 1916 [57].

During World War II, the radar technology was improved. It enabled to track aircraft in the air and determine its distance, speed, and direction. In 1990's, the first satellite systems for aircraft positioning were proposed-Global Positioning System (GPS) in 1994 and Global Navigation Satellite System (GLONASS) in 1996 [58]. All this communication/navigation and positioning systems evolved in to the stage that the presence of the pilot is not necessary in the aircraft, so-called unmanned aerial vehicle (UAV).

The evolution of early aircraft electrical systems resulted in to a demand for higher-rated generators. In the 1950's, the power output of DC generators was up to $12 \mathrm{~kW}$ at $28 \mathrm{~V}$ [59]. The highest-rated aircraft DC generator reached $18 \mathrm{~kW}$ [60]. This limitation was due to the arcing occurring on the generator's commutator at high altitudes. To supply power for all electrical loads, several parallel-connected DC generators were used on multiengine aircraft. There were also efforts to use the $120 \mathrm{~V}$-DC system; however, the problem with bulky converters and batteries and insufficient insulation material properties occurred. Another problem of DC generators was increasing the speed of engines. The limitation of insufficient amount of generated power was solved with the introduction of AC generators. However, the alternating current distribution system imposed new problems. The constant-speed-constant-frequency (CSCF) AC system was used (Figure 2(b)). AC generators, to generate constant frequency, were driven by specifically dedicated internal combustion (IC) engines. AC system had many advantages over DC system [61, 62]. AC generators could produce higher power output and were lighter-their power density was two times better. The weak arcing in the AC system did not cause significant problems [63]. Higher generated voltage level, $120 \mathrm{~V}$, enabled the reduction of wires' crosssection. AC motors were two-three times lighter than the corresponding DC motors. The change of AC voltage level could be easily done by transformers or auto-transformers, contrary to bulky and inefficient rotary converters in the case of DC voltage. In addition to frequency, another disadvantage of the AC system is the presence of reactive power and very complicated parallel generator operation [64-66].

With the introduction of semiconductors, the small aircraft, in terms of weight reduction, preferred variable speed $\mathrm{AC}$ generators and germanium rectifier (Figure 2(c)). Later, germanium was replaced by silicon.

The post-war, long-haul, commercial aircraft offered luxury services like sleeping accommodations [67]. Such aircraft needed electrical energy not only to supply vital avionics systems and important electrical systems but also to satisfy passenger demands-the galleys' ovens were used to prepare warm dishes [68]. Later, with the developing technology, the first cabin entertainment systems have been added to these services [69].

Reactive AC loads are very sensitive to frequency instability. Driving AC generators with dedicated constant-speed IC 


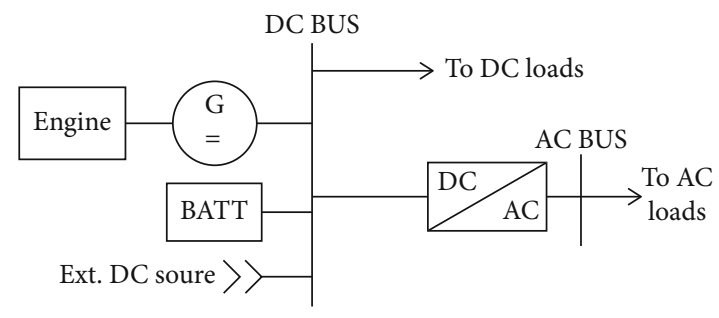

(a)

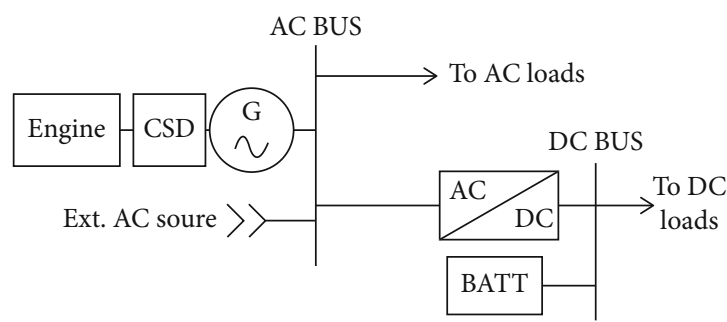

(b)

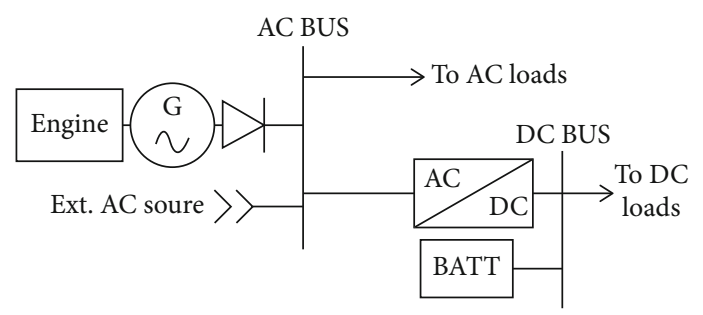

(c)

Figure 2: Power distribution: (a) for DC system; (b) for AC system; (c) for AC-DC system.

engines was not efficient, so a new type of frequency stabilisation had to be developed. In 1960's, the constant speed drive (CSD) was introduced [70]. Primarily the hydromechanical type; i.e., the generator speed was trimmed using hydraulic devices, and later, pneumatically trimmed units were used [71]. CSD is a type of transmission which the input shaft has a variable speed, proportional to the speed of the engine, and the output shaft, driving the generator, has a constant speed. In 1970's, the CSD evolved into an integrated drive generator (IDG), which is a connection of CSD and generator, sharing the same housing and cooling fluids [72-74].

Another solution to obtain constant frequency was to use a DC-link $[42,75,76]$ or a cycloconverter $[77,78]$. However, both these systems were used only by several aircraft models. Early AC generators were using slip rings. Later, three-stage wound field synchronous generators were used, and they are still in use today in many aircraft models due to their robustness, simplicity, and high efficiency [79-81]. These generators enable not to use of carbon brushes; so-called contactless construction. The next evolution in the field of generators is the removal of IDG. Instead of IDG, variablefrequency starter-generators can be used [82, 83]. Such a solution enables to remove pneumatic starters and bulky pneumatic ducting.

\section{Evolution to More/All-Electric Aircraft Concept}

To provide the necessary power for all aircraft systems (flight control, fuel and oil pumps, breaking, de-icing, lightning, cabin pressurization and air conditioning, gear extension/retraction, avionics, etc.), mechanical, electrical, pneumatic, and hydraulic power sources are used $[68,84,85]$. Once the engine is started, it is a source of power to each of these systems [86]. The power from the engine's shaft is transferred to the gearbox from which the hydraulic pumps (source of hydraulic power) and generators (source of electrical power) are driven. From the engine's compressor section (source of pneumatic power), the compressed air (bleed air) is taken. In the conventional aircraft power concept (CAPC), the pneumatic power is supplied for cabin pressurization, for anti-icing and de-icing, and for engine starting [67, 87]. Hydraulic power is supplied for flight control, landing gear extension/retraction, nose-wheel steering, braking, and thrust reversing [88]. Electric power is mainly supplied for lighting, avionics, and galleys. Mechanical power is supplied for fuel and oil pumps. In CAPC, these four powers are in relation presented in Figure 3(a).

The typical power output of one three-stage wound field synchronous generator used in midclass CAPC has been $90 \mathrm{kVA}$ with the voltage level $115 / 200 \mathrm{~V}-400 \mathrm{~Hz}[62,89]$. Such a power output was sufficient to supply all electrical loads on-board the aircraft. The gradual aircraft electrification, termed as MEA, led to a transformation of the mechanical, pneumatic, and hydraulic systems into electrical systems (Figure 3(b)) [90]. These changes had remarkable benefits on weight and fuel consumption reduction, easier component monitoring, improved system reliability, and easier and less time consuming maintenance $[6,67,91]$. There are more benefits of a single electrical system. To transfer power, there is no need to use flammable hydraulic fluids or bleed air ducting which is prone to leakage of hot air [92].

Electric motors are one of the most power-consuming electrical loads on MEA. To supply sufficient power for the motors, high-rated generators must be used. The typical power output of the starter-generators used on Boeing 787, the typical representative of MEA, is $250 \mathrm{kVA}$ for the main $\mathrm{S} / \mathrm{G}$ and $225 \mathrm{kVA}$ for auxiliary S/G. The voltage level is three-phase $230 / 400 \mathrm{~V}$-AC at variable frequency (frequency wild system) and $\pm 270 \mathrm{~V}-\mathrm{DC}$. The convenient S/Gs for MEA are induction, reluctance, and permanent magnet machines [93, 94].

In the concept of MEA, the bleed-less engine architecture is proposed; the pneumatic power is supplied only for the anti-icing system of engines' cowl [95]. A bleed-less system can decrease fuel consumption in the range of $1-2 \%$ [96]. 


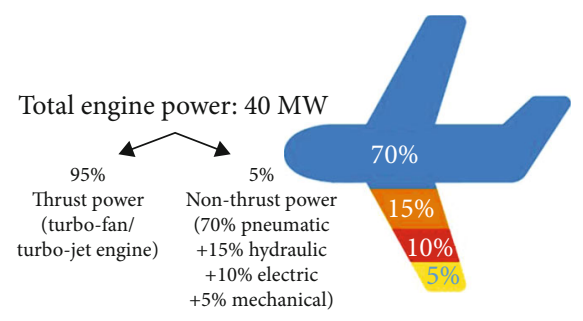

(a)

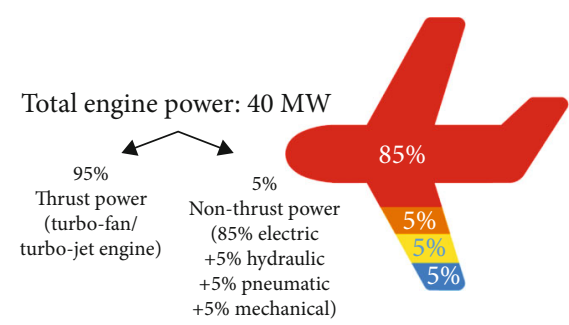

(b)

Figure 3: The nonpropulsive powers of (a) CAPC and (b) MEA.

The actuators of the control surfaces still use hydraulic power, but their local hydraulic pumps are powered electrically. Such a design, mostly used for primary flight control, is known as EHA [97, 98]. Up to now, in MEA, hydraulic power is still used for gear extension/retraction. Electrical power is used for thrust reversers $[99,100]$ and brakes [101, 102], for engine starting, for anti/de-icing of wings [103, 104], for galley's appliances [62, 105], for cabin entertainment system [106, 107], and for avionics. It is also used for electric motors of the cabin pressurization system [108, 109]. In this solution, the compressed air is not drawn from engines, but is compressed by electrically driven compressors.

Another factor which is typical for the MEA concept is the use of a decentralised/distributed power system (Figure 4). Load protection is not realized by standard mechanical circuit breakers, which must be placed in the cockpit. As a result, less wires are used. Instead of mechanical circuit breaker, the solid-state power controllers (SSPC) are used. These "electrical" circuit breakers can be placed in remote locations of the aircraft due to the possibility of digital control from the cockpit. Another advantage of SSPC is the use of MOSFET or IGBT transistors which enable soft switching of the DC or AC loads $[110,111]$. The relays and contactors are not used in the distributed power system. Such a system is much more fault-tolerant; there is no arcing and contact bouncing [112-114].

One of the systems typical for MEA is the electrical engine starting. In CAPC, the starting process is tedious. At first, the auxiliary power unit (APU) has to be started with the electrical starter motor. Then, the bleed air is fed from the APU to the pneumatic motor which is in the engine's nacelle and drives the main engine. Such a solution is also bulky due to the presence of gearbox and pneumatic ducting and suffers from higher wear and tear of the engine $[83,115]$. In MEA, the starting process is as follows: the APU is started with the starter generator. When APU has sufficient speed, its $\mathrm{S} / \mathrm{G}$ produces electrical power. This power is used to drive $S / G$ of the main engine. The advantage is that both main engines can be started simultaneously, contrary to the conventional starting system [116].

Temperature is one of the biggest problems of electrical machines implemented in aircraft. The high operating temperature is caused by high rotational speed and friction and by the power loss of the electrical system. The speed of S/G proposed in [115] is in the range of 20000 to $32000 \mathrm{rpm}$. The effect of temperature on electrical machines is investigated in $[117,118]$.

\section{The Electrical Systems Used in M/AEA}

4.1. Electrical Machines. There are many physical and operational differences between electrical machines which are used in industry and aviation [119]. The most notable difference is the voltage level. In industry, a $230 / 400 \mathrm{~V}$-AC system at 50 or $60 \mathrm{~Hz}$ is used. In aviation, $115 / 200 \mathrm{~V}-\mathrm{AC}$ at $400 \mathrm{~Hz}$ or $230 / 400 \mathrm{~V}-\mathrm{AC}$ at variable frequency and $28 \mathrm{~V}-\mathrm{DC}$ or $\pm 270 \mathrm{~V}$-DC is used [62].

There is restricted space on-board the aircraft, so the size of the components should be kept as small as possible. The selection of the electrical machine depends not only on its size and power but also on its weight. A very high power density of machines is necessary [120, 121]. Rolls Royce developed, for E Fan-X model, 2.5 MW S/G with a power density of $10 \mathrm{~kW} / \mathrm{kg}$ [122]. Additionally, the operational conditions of machines have to be considered because aircraft machines operate at a very wide range of temperatures and air pressures. The winding temperature cannot exceed $180^{\circ} \mathrm{C}$ for standard $\mathrm{H}$-class insulation and $220^{\circ} \mathrm{C}$ for R-class insulation [123]. Sufficient cooling has to be secured. Several cooling methods are proposed: cooling by using the phase change enthalpy, cooling with cold gas, oil bath cooling, water jacket cooling, and heat pipe cooling $[123,124]$. Studies on stator iron thermal enhancement, interwinding cooling, and intrawinding cooling have been performed and concluded that the improvement in the current density can be in the range of 10 to $20 \mathrm{~A} / \mathrm{mm}^{2}$, depending on the implemented cooling method [124]. In [125], the new topologies for hightemperature machines are investigated and concluded that synchronous motors with permanent magnets can be used up to $300^{\circ} \mathrm{C}$; above $300^{\circ} \mathrm{C}$, the variable reluctance machines are preferred.

In the past, aircraft was using DC brushed S/G. The purpose of this combined system was the reduction of machine size and weight because all heavy components were for both machines shared within one case. Once the engine is started, it drives the generator which produces $28 \mathrm{~V}$.

Due to the development of power transistors (MOSFETs, IGBTs), which can be easily digitally controlled, it is possible to use AC S/G $[116,126]$. In [20], the integration of S/G and its associated converter is investigated. Such a solution proposes a relatively good current density of $10-12 \mathrm{~A} / \mathrm{mm} 2$ within a small package. In [41], the implementation of the permanent magnet $S / G$ is analysed with emphasis on the flux weakening protection, as these machines suffer from the deexcitation problem. 


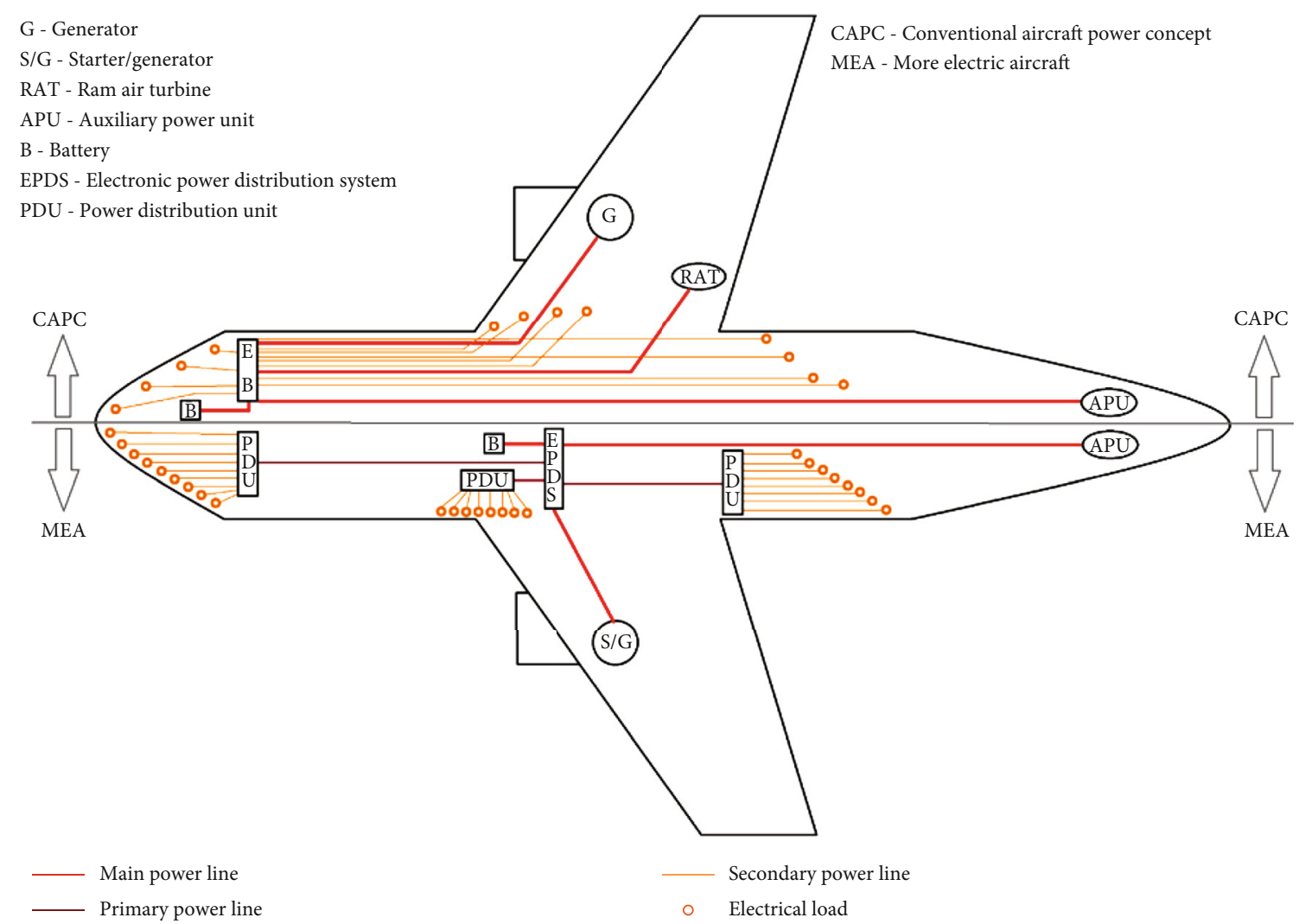

FIGURE 4: The comparison of centralised (top portion) and decentralised (bottom portion) distribution system.

The concept of integrated S/G has been defined as one of the key technologies for More Electric Engine (MEE) since the early 1990s. The integration of S/G within the engine enables to eliminate the gearbox. However, the problem with the generator position sensor occurs, which must operate within the harsh environment. In [127], the sensorless integrated S/G is proposed. Many various S/Gs are being studied for aerospace applications (Figure 5); these are permanent magnet synchronous machines (PMSMs) [128-131], induction machines (IMs) [132-135], switched reluctance machines (SRMs) [136-143], and wound rotor synchronous machine (WRSM) [94, 144-147].

WRSMs are widely used in CAPC as AC generators; however, due to the digital control of power converters, they can find its application in MEA as S/G with high power density, high reliability, and simple maintenance features [147]. Additionally, high power factor at wide speed range, reduced voltage transients, and improved electrical safety is the advantages of WRSM [144]. On the other hand, complicated control schemes, complex starting control, and running speed limit are considered as disadvantages [145].

IMs are very often used in industry. They are reliable, require low maintenance, and they have a low cost of construction. IMs are suitable for operation in harsh environment, they can withstand very high temperatures [148]. They can be easily controlled to operate in a wide speed range. Their drawback is low torque value during starting mode, low power factor, and the power decrease during high-speed operation [149].
Permanent magnet synchronous machines have gained popularity with the emergence of stronger magnetic materials in recent years. PMSMs are highly efficient and have high power density since there is no active component in the rotor. On the other hand, they require a supplementary protection system for safety, and if power electronic components fails, high terminal voltage could appear [150]. They have complex control strategies for magnetic flux control, and there is a risk of demagnetization of magnets [151].

SRM has superior fault tolerance for operation in a harsh environment, easy and low-cost maintenance, and has high start-up torque and inherent overcurrent protection [139, 141]. However, the control of SRMs is quite complicated. They have also low efficiency, around $80 \%$, and high voltage ripples in generator mode [142].

4.2. Flight Control Surfaces. The hydraulics is still the main power source used for the operation of flight controls on both, MEA and CAPC. The main aircraft control surfaces and their power supplies are presented in Figure 6. Usually, two flaps on each wing are operated hydraulically and electrical power is used as a backup. The same principle is used for spoilers, elevators, and rudders. However, hydraulic systems have many disadvantages [152]:

(i) The use of flammable and not environmentally friendly hydraulic fluid 


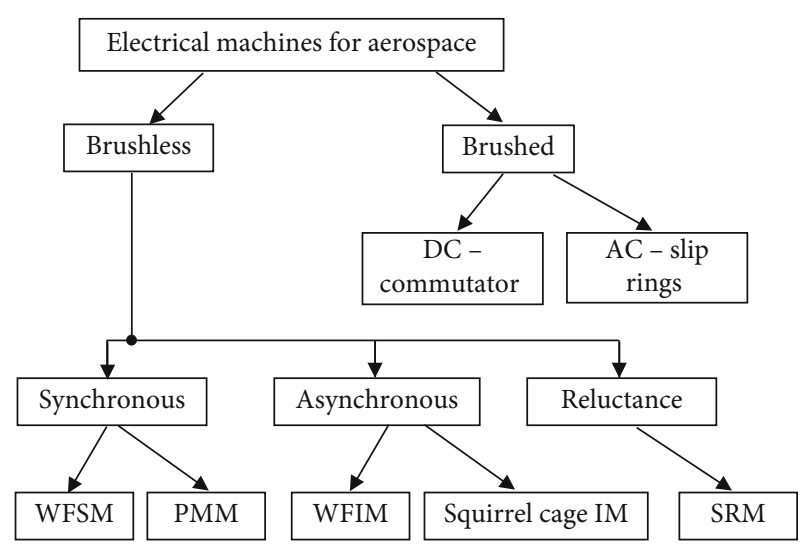

Figure 5: Electrical machines for aerospace applications.

(ii) The leakage of hydraulic fluid results in the loss of actuation power

(iii) The need to maintain the full system pressure ( 3000 psi to $5000 \mathrm{psi}$ ), also when the system is not used

(iv) The hydraulic system is bulky and requires costly maintenance

To eliminate these disadvantages, the flight controls in MEA will be operated electrically [153]. The electrification process can be seen in Figure 5 at the horizontal stabilizer, which is operated solely by electric power. The electrical machines to be used must operate as reliably as conventional systems with an overall fault probability of $10^{-9}$ [154]. Considering these working conditions, PMSMs with the high power density and high efficiency can be implemented here as electromechanical actuator (EMA) [153].

\section{Electric Steering and Taxiing Systems}

Another component that is hydraulically operated in today's aircraft is the nose wheel steering system. A steering mechanism is used to enable the plane to turn to the right or left during taxiing. In MEA, the steering mechanism will be electrically driven.

Linear actuators that use three-phase axial flux permanent magnet machines are potential candidates to operate the steering mechanism [155-157], as they provide high torque at low speed, and they are very compact [157]. An electric steering system can be preferably used with electric taxiing, so during the taxiing, only electric power can be used.

Another system to be implemented in MEA is the electric taxiing system (ETS). ETS enables the aircraft to move from an airport platform to the runway entirely with electric power, without the use of main engines. This will be achieved by electrical machines powered by fuel cells integrated in the landing gear.

Electric taxiing will provide fuel savings and a decrease of noise and air pollution, normally caused by the engines [158]. At Heathrow airport in 2002, it was estimated that $56 \%$ of the NOx were from taxi operations [159]. It is estimated that the global family of short-haul aircraft burns around five million tons of fuel per year during taxiing [160]. ETS will save up to $2 / 3$ of what airlines currently spend on fuel for taxi operations [160]. There will be also time savings because the use of tractors for push-back is not necessary.

There are two methods of ETS which are under inspection-on-board and external taxiing. External ETS uses an external source of electricity-electric tug tractors. Current research and tests are focused on on-board ETS which can be installed on the nose wheel or main landing gear. The advantage of on-board ETS is that the aircraft can be fully autonomous on each airfield. However, if there is a requirement for short-radius turning, the ETS on nose wheel has restricted ability [161].

There are several types of drive units considered for ETS, i.e., IM, PMSM, and PM brushless DC motors [162]. When ETS is integrated in the main landing gear, the issue of increased temperatures has to be solved. PMSMs are not stable with temperature. Moreover, high back-EMF values could be a problem when using PMSMs what leads to winding failure [158].

5.1. High-Temperature Superconductor Machines. The AEA is an aircraft with electric propulsion, in which all nonpropulsive powers are entirely electric. Conventional electric motors do not provide sufficient power density to be used for electric propulsion on large aircraft [120]. The implementation of superconducting materials in electrical drives was not realisable, due to the requirement of very low temperatures, reaching only several Kelvins.

With the discovery of high-temperature superconductors in 1986 [163, 164], the work in the field of electric propulsion gained speed. Many HTS engine designs and tests have been performed [165-170]. The advantages of HTS motors are low weight, compact size, very high power densities, and negligible DC loss; however, AC loss of HTS winding must be minimised [168]. For that purpose, HTS rotor and stator windings, instead of conventional copper windings, are used [169].

Two cooling methods are proposed for HTS machines, the cryocooler , and cryogenic liquid. Cryocoolers are designed mostly for ground operations. Their efficiency is lower than $10 \%$ [165]. Cryogenic liquids can be used in open-loop or close-loop systems. The close-loop systems are heavier, so their application is rather convenient for large aircraft. Contrary, the open-loop system is lighter and needs only cryogenic liquid, so it can be applied also to small aircraft [169]. In [170], hydrogen at $20 \mathrm{~K}$ is proposed as the cooling liquid for HTS generator with effective power $10 \mathrm{MW}$, power density $20 \mathrm{~kW} \mathrm{~kg}^{-1}$, line voltage $3 \mathrm{kV}$, and coils' current density $300 \mathrm{~A} \mathrm{~mm}^{-2}$.

5.2. Fuel Cells for M/AEA Aircraft. The AEAs rely entirely on electrical power. Present technologies, in general, do not enable aircraft to use only electric motors for propulsion, due to the limitations of power sources. Typical energy densities of today's lithium-ion batteries are $100-265 \mathrm{Wh} / \mathrm{kg}$ depending on whether the battery is optimized for peak power or long life [171]. Such energy densities are sufficient only for small aircraft with a restricted range of flight. 


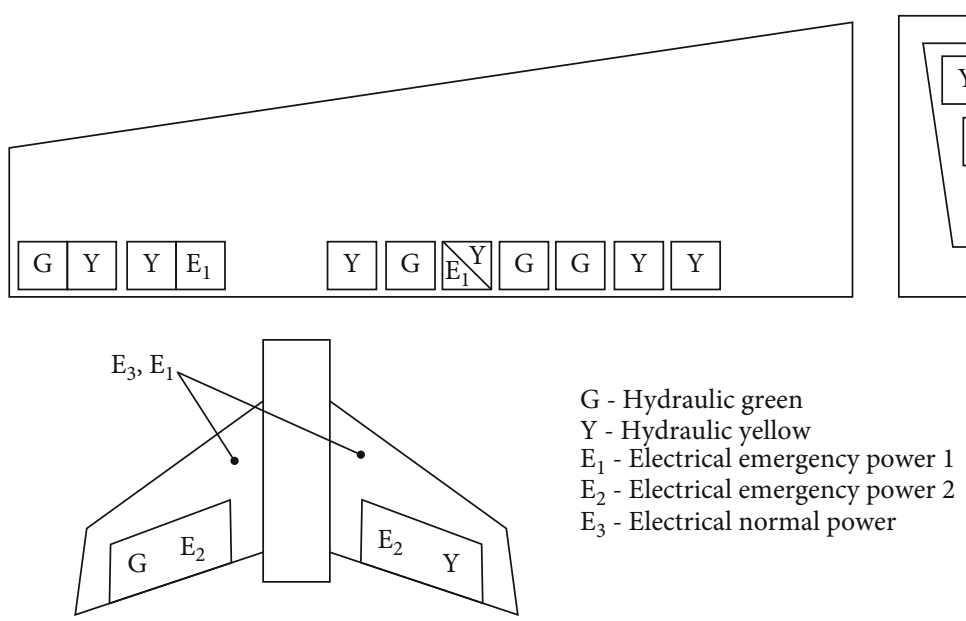

Figure 6: Aircraft main control surfaces.

According to many studies, the battery energy density for long-haul AEA has to be at least $500 \mathrm{Wh} / \mathrm{kg}[172,173]$. Such an energy density can be achieved by lithium-sulphur batteries with a theoretical limit of $2700 \mathrm{Wh} / \mathrm{kg}$ [173].

Another approach to on-board electric power sources is the use of FCs based on the chemical reactions of hydrogen and oxygen. There are several tests of FCs suitable for aviation [174]; these are solid-oxide FC and proton exchange membrane FC. At first, the use of FCs is meant as a replacement for APU's jet engine. Such a solution can be combined with electric taxiing. Another goal of FC is to supply energy for propulsion to enhance the overall efficiency of the propulsion system. Such a combination of jet engine and electric motor for propulsion is termed as hybrid-electric aircraft.

The product of FC is not only electrical energy but also heat, water, and air depleted of oxygen, which can be further utilized on-board the aircraft [175]. The efficiency of the current FC is around 50\%, while the efficiency of APU is after many years of improvement not more than $20 \%$ [176].

The current drawback of using FC on-board the aircraft is its heavier weight and volume compared to the traditional system, mainly due to the storage problems of hydrogen. There are three possibilities of how to store hydrogen. The first one is to use compressed gaseous hydrogen; however, this solution is very bulky. The second solution is to use cryo-compressed hydrogen, and the third possibility is to use liquid hydrogen (LH2). LH2 must be stored within cryogenic temperature (at most $33 \mathrm{~K}$ ) in spherical-shaped tanks, which are very impractical compared to traditional fuel tanks. The volume of LH2 is four times bigger than the volume of kerosene at the same energy content; however, its weight is 2.8 times smaller [177].

5.3. Energy Harvesting in Aviation. The AEA will be acceptable only if they can fly for long distances; therefore, the weight of the aircraft should be kept as low as possible. The low weight and complex aircraft structure will require constant structural health monitoring (SHM). The traditional SHM uses sensors supplied from the primary cells and the signal is supplied to the computer by wire. In this regard, the wireless sensor network (WSN) for SHM is proposed
$[178,179]$. The power levels of these sensors are in the range of 10-50 MW, depending on the data rate [180]. These sensors will harvest energy from the environment. There are proposed several energy harvesting $(\mathrm{EH})$ methods for aeronautical applications, i.e., the usage of thermal gradients, solar radiation, vibration, and airflow. The transducers such as photovoltaic generators, thermoelectric generators, electromagnetic, piezoelectric and triboelectric converters, and radio frequency transducers are used. Experiments on the integration of piezoelectric EH elements into the carbonfiber composite structure are performed to eliminate the major drawback of piezoelectric element-brittleness [181]. In [182], the EH concept for treating electrostatic energy produced by flying composite aircrafts is proposed. Static charges can be collected with capacitive collectors. Energy harvesting is especially preferable for UAVs [182]. In [183, 184], a wireless communication system with $\mathrm{EH}$ to transfer information from UAV to ground is proposed. Another research on $\mathrm{EH}$ is aimed at prolonging the UAV flight time by dynamic soaring [185] or the use of solar power [186].

\section{Conclusions}

Current aircraft are very complex. They use hydraulic, pneumatic, mechanical, and electrical systems to handle extreme operational conditions. However, the use of four different powers on-board the aircraft results in their bigger overall weight and complexity. This has a negative impact on fuel consumption and maintenance cost/time. Therefore, there is long-term effort to use only one, the most effective power system-electrical system. The use of electrical power is a more efficient way to supply loads than the extraction of the engine's bleed air (pneumatic power). Bleed-less architecture is supposed to extract $35 \%$ less power from the engine [187].

As a result, a lot of studies on M/AEA have been performed. The key component of aircraft electrification is the use of high power density electrical machines (generators, motors, and converters) and a new type of "intelligent" power distribution system with digitally controlled electronic circuit breakers. 
Regarding the environment, there is a big effort to reduce the emissions produced by aircraft. This can be achieved by replacing the traditional engines, combusting fuel based on hydrocarbons, by propulsion with electric motors-AEA. However, this concept is still not feasible for midsize and large-size aircraft due to the restricted capacity of electrical power sources, but is vital for small private and general aviation aircraft. By the time the power sources for AEA would be improved, the concept of HEA is a promising idea. The fuel saving of $20-30 \%$ is expected by 2035 , within the shortmedium range HEA [188].

\section{Conflicts of Interest}

The authors declare that there is no conflict of interest regarding the publication of this paper.

\section{Acknowledgments}

The authors would like to thank the grant project KEGA 044TUKE-4/2019-a small unmanned airplane-the platform for education in the area of intelligent avionics.

\section{References}

[1] Ç. Cakir, M. Yalcin, Ö. Ozkan, L. Buyuktanir Ozdemir, and E. Dolek, "Environmental impact assessment implementations for transport sector," in Uluslararası ÇED Kongresi 810 Kasım 2013, pp. 341-351, İstanbul, 2013.

[2] A. Nagy, "Electric aircraft-present and future," Production Engineering Archives, vol. 23, no. 23, pp. 36-40, 2019.

[3] N. Morioka, M. Takeuchi, and H. Oyori, "Moving to an allelectric aircraft system," IHI Engineering Review, vol. 47, no. 1, pp. 33-39, 2014.

[4] M. Schrötter, R. Bréda, R. Andoga, and L. Főző, "The evolution of the aircraft electric power systems," in 2018 International IEEE Conference and Workshop in Óbuda on Electrical and Power Engineering (CANDO-EPE), pp. 159162, Budapest, Hungary, 2018.

[5] L. Setlak, "Overview of aircraft technology solutions compatible with the concept of MEA," in Czasopismo Techniczne, pp. 67-76, Elektrotechnika, 2015.

[6] R. I. Jones, "The more electric aircraft-assessing the benefits," Proceedings of the Institution of Mechanical Engineers, Part G: Journal of Aerospace Engineering, vol. 216, no. 5, pp. 259-269, 2002.

[7] J. A. Rosero, J. A. Ortega, E. Aldabas, and L. Romeral, "Moving towards a more electric aircraft," IEEE Aerospace and Electronic Systems Magazine, vol. 22, no. 3, pp. 3-9, 2007.

[8] J. J. Treacy, "Flight safety issues of an all-electric aircraft," IEEE Transactions on Aerospace and Electronic Systems, vol. AES-20, no. 3, pp. 227-233, 1984.

[9] D. P. Rubertus, L. D. Hunter, and G. J. Cecere, "Electromechanical actuation technology for the all-electric aircraft," IEEE Transactions on Aerospace and Electronic Systems, vol. AES-20, no. 3, pp. 243-249, 1984.

[10] R. Winblade, "The all-electric airplane: what is it?," IEEE Transactions on Aerospace and Electronic Systems, vol. AES20, no. 3, pp. 211-212, 1984.

[11] C. R. Spitzer, "The all-electric aircraft: a systems view and proposed NASA research programs," IEEE Transactions on
Aerospace and Electronic Systems, vol. AES-20, no. 3, pp. 261-266, 1984.

[12] J. D. Engelland, "The evolving revolutionary all-electric airplane," IEEE Transactions on Aerospace and Electronic Systems, vol. AES-20, no. 3, pp. 217-220, 1984.

[13] S. F. Follett, "Electrical equipment in aircraft: survey of past and present practice and future trends in design," Proceedings of the IEE Part A: Power Engineering, vol. 103, no. 1S, p. 4, 1956.

[14] G. Friedrich and A. Girardin, "Integrated starter generator," IEEE Industry Applications Magazine, vol. 15, no. 4, pp. 2634, 2009.

[15] B. S. Bhangu and K. Rajashekara, "Electric starter generators: their integration into gas turbine engines," IEEE Industry Applications Magazine, vol. 20, no. 2, pp. 14-22, 2014.

[16] P. Wheeler, "Technology for the more and all electric aircraft of the future," in 2016 IEEE International Conference on Automatica (ICA-ACCA),, Curico, Chile, 2016.

[17] A. S. Gohardani, G. Doulgeris, and R. Singh, "Challenges of future aircraft propulsion: a review of distributed propulsion technology and its potential application for the all electric commercial aircraft," Progress in Aerospace Science, vol. 47, no. 5, pp. 369-391, 2011.

[18] Y. Xie, T. Antonios, Z. Dan, and G. Jason, "Review of hybrid electric powered aircraft, its conceptual design and energy management methodologies," Chinese Journal of Aeronautics, vol. 34, no. 4, pp. 432-450, 2020.

[19] A. Misra, Technical Challenges and Barriers Affecting TurboElectric and Hybrid Electric Aircraft Propulsion, 2017, March 2020, http://ntrs.nasa.gov/api/citations/20180004252/ downloads/20180004252.pdf.

[20] A. Balachandran, M. Boden, Z. Sun, S. J. Forrest, J. D. Ede, and G. W. Jewell, "Design, construction, and testing of an aero-engine starter-generator for the more-electric aircraft," Journal of Engineering, vol. 2019, no. 17, 3478 pages, 2019.

[21] B. J. Brelje and J. R. R. A. Martins, "Electric, hybrid, and turboelectric fixed-wing aircraft: a review of concepts, models, and design approaches," Progress in Aerospace Science, vol. 104, pp. 1-19, 2019.

[22] A. K. Sehra and W. Whitlow, "Propulsion and power for 21st century aviation," Progress in Aerospace Sciences, vol. 40, no. 4-5, pp. 199-235, 2004.

[23] A. S. Gohardani, "A synergistic glance at the prospects of distributed propulsion technology and the electric aircraft concept for future unmanned air vehicles and commercial/military aviation," Progress in Aerospace Science, vol. 57, pp. 25-70, 2013.

[24] “A giant leap towards zero-emission flight," 2021, https:// www.airbus.com/innovation/zero-emission/electric-flight/efan-x.html.

[25] "Hybrid Power Module," 2021, http://www.voltaero.aero/en/ propulsion/hybrid-power-module/.

[26] "Safran's ENGINeUS ${ }^{\mathrm{TM}}$ electric motors will fly on the VoltAero Cassio 1 hybrid-electric testbed aircraft," 2021, https://www.safran-electrical-power.com/media/safransengineustm-electric-motors-will-fly-voltaero-cassio-1hybrid-electric-testbed-aircraft-20191023.

[27] "Breakthrough performance for a new age of aviation," 2021, http://zunum.aero/technology/.

[28] “ESAero ECO-150," 2021, https://www.esaero.com/eco-150project-information. 
[29] "Diamond Aircraft proudly presents the world's first serial hybrid electric aircraft "DA36 E-Star"," 2021, https://www .diamondaircraft.com/en/about-diamond/newsroom/news/ article/diamond-aircraft-proudly-presents-the-worlds-firstserial-hybrid-electric-aircraft-da36-e-star/.

[30] "Electric Aircraft with real utility," 2021, https://www .ampaire.com/.

[31] C. E. D. Riboldi, "Energy-optimal off-design power management for hybrid-electric aircraft," Aerospace Science and Technology, vol. 95, p. 105507, 2019.

[32] E. Bongermino, M. Tomaselli, V. G. Monopoli, G. Rizzello, F. Cupertino, and D. Naso, "Hybrid aeronautical propulsion: control and energy management," IFAC-Papers OnLine, vol. 50, no. 2, pp. 169-174, 2017.

[33] T. Lei, Z. Yang, Z. Lin, and X. Zhang, "State of art on energy management strategy for hybrid-powered unmanned aerial vehicle," Chinese Journal of Aeronautics, vol. 32, no. 6, pp. 1488-1503, 2019.

[34] T. Donateo and L. Spedicato, "Fuel economy of hybrid electric flight," Applied Energy, vol. 206, pp. 723-738, 2017.

[35] J. Ribeiro, F. Afonso, I. Ribeiro et al., "Environmental assessment of hybrid-electric propulsion in conceptual aircraft design," Journal of Cleaner Production, vol. 247, p. 119477, 2020.

[36] E. Baharozu, G. Soykan, and M. B. Ozerdem, "Future aircraft concept in terms of energy efficiency and environmental factors," Energy, vol. 140, pp. 1368-1377, 2017.

[37] T. Schröter and D. Schulz, "Power management on aircraft: flight-phase-dependent network design for electrical networks with limited resources," in 2017 2nd International Conference on System Reliability and Safety (ICSRS), pp. 360-367, Milan, Italy, 2017.

[38] D. Schlabe and J. Lienig, "Energy management of aircraft electrical systems-state of the art and further directions," in 2012 Electrical Systems for Aircraft, Railway and Ship Propulsion, Bologna, Italy, 2012.

[39] M. Kim, S. G. Lee, and S. Bae, "Decentralized power management for electrical power systems in more electric aircrafts," Electronics, vol. 7, no. 9, p. 187, 2018.

[40] F. Adamčík, M. Schrötter, M. Češkovič, and J. Leško, “The necessity of decentralized aircraft power distribution system implementation," in 2019 Modern Safety Technologies in Transportation (MOSATT), Kosice, Slovakia, 2019.

[41] Z. Zhang, J. Li, Y. Liu, Y. Xu, and Y. Yan, "Overview and development of variable frequency AC generators for more electric aircraft generation system," Chinese Journal of Electrical Engineering, vol. 3, no. 2, pp. 32-40, 2017.

[42] E. F. C. Freitas and N. E. Daidzic, "Design of DC-link VSCF AC electrical power system for the Embraer 190/195 aircraft," Journal of Aviation Technology and Engineering, vol. 7, no. 1, 2017.

[43] P. J. Masson and C. A. Luongo, "High power density superconducting motor for all-electric aircraft propulsion," IEEE Transactions on Appiled Superconductivity, vol. 15, no. 2, pp. 2226-2229, 2005.

[44] K. Kovalev, J. Nekrasova, N. Ivanov, and S. Zhurzvlev, "Design of all-superconducting electrical motor for full electric aircraft," in International Conference on Electrotechnical Complexes and Systems (ICOECS), Ufa, Russia, 2019.

[45] M. Corduan, M. Boll, R. Bause, M. Oomen, M. Filipenko, and M. Noe, "Topology comparison of superconducting AC machines for hybrid electric aircraft," IEEE Transactions on Applied Superconductivity, vol. 30, no. 2, pp. 1-10, 2020.

[46] F. Berg, J. Palmer, L. Bertola, P. Miller, and G. Dodds, "Cryogenic system options for a superconducting aircraft propulsion system," IOP Conference Series: Materials Science and Engineering, vol. 101, p. 012085, 2015.

[47] “Tissandier Electric Airship," 2021, https://www .thisdayinaviation.com/tag/tissandier-electric-airship/.

[48] E. Torenbeek and H. Wittenberg, "History of aviation," in Flight Physics, pp. 1-46, Springer, Dordrecht, 2009.

[49] F. I. T. Petrescu and R. V. Petrescu, The Aviation History, Books on Demand GmbH, Norderstedt Editor: Books On Demand, 2012.

[50] S. M. Berkowitz, "Airplane performance, stability and control," Journal of the Franklin Institute, vol. 249, no. 6, pp. 503-504, 1950.

[51] M. J. Abzug and E. E. Larrabee, Airplane Stability and Control, Second Edition, Cambridge University Press, Cambridge, UK, 2002.

[52] J. P. Beaujard, Airbus flight control systems and future evolutions, Occasion of the National Day of Reflection and Foresight on Embedded Systems, 2003, https://slideplayer.com/ slide/3110094/.

[53] V. Barshevskiy, The Helicopter, from the Original (Gelicopter), Moscow, 1949.

[54] N. Yadaiah, A Comprehensive Reference Guide for Certified Indigenous Batteries, Compendium of Military Aviation Batteries, 2009, 2021, https://www.drdo.gov.in/sites/default/ files/inline-files/Batteries_Compendium_0.pdf.

[55] V. Madonna, P. Giangrande, and M. Galea, "Electrical power generation in aircraft: review, challenges, and opportunities," IEEE Transactions on Transportation Electrification, vol. 4, no. 3, pp. 646-659, 2018.

[56] "1st Air Mechanic C.S. Britten, Wireless Operator RFC Interviewed 13th December 1978," 2021, https://archive.is/ 20130123134641/http://www.freewebs.com/voicesinflight/ cyrilbritten.htm.

[57] "Did You Know When Pilots Started To Communicate Using Radio?," 2021, https://www.baatraining.com/pilots-usingradio/.

[58] “GNSS For Aviation a Brief Background," 2021, https://www .icao.int/APAC/Meetings/2011_WKSHP_GNSS/SP01_ ICAO\%20GNSS\%20for\%20Aviation.pdf.

[59] A. C. Paralleled, "The case for constant-frequency systems," in Flight and Aircraft Engineer, pp. 164-166, ILiffe \& Sons Ltd, Kettering, England[88] Renewable and Sustainable Energy Reviews 6(5):29-35, Elsevier, 1959.

[60] A. I. Bertinov, "Aircraft electrical generators," Translation from the original (Aviatsionnryyo Elektricheskiye Mashiny), 1959, 2021, https://apps.dtic.mil/dtic/tr/fulltext/u2/601545 .pdf.

[61] T. K. Eismin, Aircraft Electricity and Electronics, McGrawHill Education, New York, United States, 2014.

[62] I. Moir, A. Seabridge, and M. Jukes, Civil Avionics Systems, John Wiley \& Sons, 2013.

[63] J. Andrea, M. Buffo, E. Guillard, R. Landfried, R. Boukadoum, and P. Teste, "Arcing fault in aircraft distribution network," in 2017 IEEE Holm Conference on Electrical Contacts, Denver, CO, USA, 2017.

[64] L. R. Larson, "Parallel operation of aircraft A-C generators," Transactions of the American Institute of Electrical Engineers, 
Part II: Applications and Industry, vol. 72, no. 6, pp. 403-407, 1954.

[65] H. A. Kahle, "Parallel operation of aircraft A-C generators: reactive load division and selective protection," Transactions of the American Institute of Electrical Engineers, Part II: Applications and Industry, vol. 75, no. 3, pp. 175-181, 1956.

[66] D. E. Baker and E. R. Honigford, "Parallel operation of VSCF electrical power generators," in SAE Technical Paper Series, pp. 1098-1107, Anaheim, California, USA, 1988.

[67] M. J. J. Cronin, “The all-electric aircraft," IEE Review, vol. 36, no. 8, pp. 309-311, 1990.

[68] W. Boughton, "Present-day and probable future electrical applications in aircraft," Electrical Engineering, vol. 57, no. 3, pp. 169-170, 1938.

[69] "History of In-Flight Entertainment Systems: How it all began,” 2021, https://www.lhsystems.com/blog-entry/ history-flight-entertainment-systems-how-it-all-began.

[70] E. W. Giloy, "Performance of a constant-speed drive," Transactions of the American Institute of Electrical Engineers, Part II: Applications and Industry, vol. 73, no. 4, pp. 179-184, 1954.

[71] R. L. Smith, "The plessey constant speed drive/starter and its application to the BAC 1-11 commercial transport," in SAE Technical Paper Series, USA, 1967.

[72] R. J. Kennett, "Integrated drive generators for aircraft," Electronics and Power, vol. 17, no. 2, pp. 73-76, 1971.

[73] M. A. Cordner, W. A. Flygare, and D. H. Grimm, U.S. Patent No. 4,252,035, Patent and Trademark Office, Washington, DC: U.S, 1981.

[74] H. R. Vanderzyden and J. C. Dell, U.S. Patent No. 9,154,011, Patent and Trademark Office, Washington, DC: U.S, 2015.

[75] M. A. Rosswurm, "Design considerations of DC-link aircraft generation systems," in SAE Technical Paper Series, pp. 35013515, USA, 1981.

[76] K. Zhang, L. Wen, Z. Geng, and D. Czarkowski, “A comparative study of AC-link and DC-link based frequency converters," in 2018 IEEE International Conference on Applied System Invention (ICASI), pp. 461-464, Chiba, Japan, 2018.

[77] D. O. Burns, "Use of cycloconverters and variable speed alternators as engine starters," Aircraft Engineering and Aerospace Technology, vol. 44, no. 10, pp. 8-12, 1972.

[78] W. McMurray, "Frequency converter technology for aircraft power systems," Journal of Energy, vol. 6, no. 5, 333 pages, 1982.

[79] A. Sharma, G. K. Capoor, and A. B. Chattopadhyay, "Advanced aircraft electrical systems to enable an allelectric aircraft," in 2015 International Conference on Electrical Systems for Aircraft, Railway, Ship Propulsion and Road Vehicles (ESARS), Aachen, Germany, 2015.

[80] Y. Wang, S. Nuzzo, H. Zhang, W. Zhao, C. Gerada, and M. Galea, "Challenges and opportunities for wound field synchronous generators in future more electric aircraft," IEEE Transactions on Transportation Electrification, vol. 6, no. 4, pp. 1466-1477, 2020.

[81] G. Dinesh, B. V. Adithya, and V. Vedula, "Modeling of a traditional aircraft generator and its sub-systems," in 2015 IEEE International Conference on Electrical, Computer and Communication Technologies (ICECCT), pp. 1-7, Coimbatore, India, 2015.

[82] K. Xu, N. Xie, C. Wang, and X. Shi, "Modeling and simulation of variable speed variable frequency electrical power sys- tem in more electric aircraft," The Open Electrical \& Electronic Engineering Journal, vol. 11, no. 1, 2017.

[83] J. K. Nøland, M. Leandro, J. A. Suul, and M. Molinas, "Highpower machines and starter-generator topologies for more electric aircraft: a technology outlook," IEEE Access, vol. 8, pp. 130104-130123, 2020.

[84] R. I. Jones, "The more electric aircraft: the past and the future?", in IEE Colloquium. Electrical Machines and Systems for the More Electric Aircraft, pp. 1-4, London, UK, 1999.

[85] I. O. Hockmeyer, "The generation and regulation of electric power in aircraft: a survey of design features of generators and their control," Journal of the Institution of Electrical Engineers - Part II: Power Engineering, vol. 93, no. 31, pp. 2-14, 1946.

[86] "Safran and Aviation's Electric Future," 2021, https://www .safran-group.com/file/download/dp_safran_bourget_2019_ safran_and_aviations_electric_future_en.pdf.

[87] I. Moir, "The all-electric aircraft - major challenges," in IEE Colloquium on All Electric Aircraft, London, UK, 1998.

[88] D. B. Jani, S. Ashish, S. Aditya et al., An Overview on Aircraft Hydraulic System, 2019.

[89] J. Chang and A. Wang, "New VF-power system architecture and evaluation for future aircraft," IEEE Transactions on Aerospace and Electronic Systems, vol. 42, no. 2, pp. 527539, 2006.

[90] W. Cao, B. C. Mecrow, G. J. Atkinson, J. W. Bennett, and D. J. Atkinson, "Overview of electric motor technologies used for more electric aircraft (MEA)," IEEE Transactions on Industrial Electronics, vol. 59, no. 9, pp. 3523-3531, 2012.

[91] J. S. Cloyd, "A status of the United States Air Force's more electric aircraft initiative," in IECEC-97 Proceedings of the Thirty-Second Intersociety Energy Conversion Engineering Conference (Cat. No.97CH6203),, Honolulu, HI, USA, 1997.

[92] S. Sallem, L. Sommervogel, M. Olivas, and A. Peltier, "Method and device for hot air leak detection in aircraft installation by wire diagnosis," in 2016 IEEE AUTOTESTCON, pp. 1-6, Anaheim, CA, USA, 2016.

[93] J. K. Noland, M. Leandro, J. A. Suul, M. Molinas, and R. Nilssen, "Electrical machines and power electronics for starter-generators in more electric aircrafts: a technology review," in IECON 2019 - 45th Annual Conference of the IEEE Industrial Electronics Society, pp. 6994-7001, Lisbon, Portugal, 2019.

[94] N. Jiao, W. Liu, J. Pang, Z. Zhang, and Y. Jiang, "Integrated model of brushless wound-rotor synchronous startergenerator based on improved parametric average-value model of rotating rectifier," International Journal of Electrical Power \& Energy Systems, vol. 96, pp. 106-113, 2018.

[95] “ENGINES," 2021, https://www.boeing.com/commercial/ aeromagazine/articles/qtr_4_07/article_02_2.html.

[96] "787 No-Bleed Systems: Saving Fuel and Enhancing Operational Efficiencies," 2021, http://www.boeing.ch/ commercial/aeromagazine/articles/qtr_4_07/AERO_Q407_ article2.pdf.

[97] D. Van Den Bossche, "The A380 flight control electrohydrostatic actuators, achievements and lessons learnt," in 25th international congress of the aeronautical sciences, pp. 1-8, Hamburg, Germany, 2006.

[98] W. Lee, S. Li, D. Han, B. Sarlioglu, T. A. Minav, and M. Pietola, "A review of integrated motor drive and widebandgap power electronics for high-performance electro- 
hydrostatic actuators," IEEE transactions on transportation electrification, vol. 4, no. 3, pp. 684-693, 2018.

[99] “Aircelle's Electrical Thrust Reverser Actuation System Passes Key Milestone for its Service Introduction on the A380," 2021, https://www.safran-nacelles.com/media/ 20060728_aircelles-electrical-thrust-reverser-actuationsystem-passes-key-milestone-its-service-introduction-a380.

[100] A. Johnson, "Electric thrust reverser actuation systems," in SAE Technical Paper Series, Phoenix, Arizonia, USA, 2002.

[101] L. Bo and Y. Li, "Research on simulation of aircraft electric braking system," in In Recent Advances in Computer Science and Information Engineering, pp. 301-309, Springer, Berlin, Heidelberg, 2012.

[102] "Electric brake," 2021, https://www.safran-landing-systems .com/wheels-and-brakes/technologies/electric-brake.

[103] Z. Goraj, "An overview of the deicing and anti-icing technologies with prospects for the future," 24th international congress of the aeronautical sciences, vol. 29, 2004.

[104] V. Pommier-Budinger, M. Budinger, P. Rouset et al., "Electromechanical resonant ice protection systems: initiation of fractures with piezoelectric actuators," AIAA Journal, vol. 56, no. 11, pp. 4400-4411, 2018.

[105] W. D. Aronson, J. C. Dettmer, and S. A. Ramus, U.S. Patent No. 8,289,670, Patent and Trademark Office, Washington, DC: U.S, 2012

[106] "Power trip: The major drains of modern aircraft cabin electrical power," 2021, https://www.aviationbusinessnews.com/ cabin/aircraft-cabin-ife-connectivity/.

[107] A. Akl, T. Gayraud, and P. Berthou, "A new wireless architecture for In-Flight Entertainment systems inside aircraft cabin," International Journal on Advances in Networks and Services, vol. 4, no. 1\&2, pp. 159-175, 2011.

[108] Y. Yang and Z. Gao, "Power optimization of the environmental control system for the civil more electric aircraft," Energy, vol. 172, pp. 196-206, 2019.

[109] R. Vega Diaz, Analysis of an Electric Environmental Control System to Reduce the Energy Consumption of Fixed-Wing and Rotary-Wing Aircraft, Cranfield University, UK, 2011.

[110] R. Fuller and Z. Liu, U.S. Patent No. 8,861,162, Patent and Trademark Office, Washington, DC: U.S, 2014.

[111] G. I. Rozman and S. M. Waleed, U.S. Patent No. 8,338,983, Patent and Trademark Office, Washington, DC: U.S, 2012.

[112] D. A. Molligoda, P. Chatterjee, C. J. Gajanayake, A. K. Gupta, and K. J. Tseng, "Review of design and challenges of DC SSPC in more electric aircraft," in 2016 IEEE 2nd Annual Southern Power Electronics Conference (SPEC), pp. 1-5, Auckland, New Zeland, 2016.

[113] A. Valko, J. Petrella, D. Murray, D. Frederick, and K. Alves, "Solid-state secondary power distribution," Final Report, DOT/FAA/TC-13/19, 2014.

[114] M. Terörde, F. Grumm, D. Schulz, H. Wattar, and J. Lemke, "Implementation of a solid-state power controller for highvoltage DC grids in aircraft," in Power and Energy Student Summit (PESS) 2015, January 13th-14th, Technical university Dortmund, Institute of Energy Systems, Energy Efficiency and Energy Economics, Dortmund Germany, 2015.

[115] S. Bozhko, T. Yang, J.-M. Le Peuvedic et al., "Development of aircraft electric starter-generator system based on active rectification technology," IEEE Transactions on Transportation Electrification, vol. 4, no. 4, pp. 985-996, 2018.
[116] M. E. Elbuluk and M. D. Kankam, "Potential starter/generator technologies for future aerospace applications," IEEE Aerospace and Electronic Systems Magazine, vol. 12, no. 5, pp. 24-31, 1997.

[117] A. Boglietti, A. Cavagnino, D. Staton, M. Shanel, M. Mueller, and C. Mejuto, "Evolution and modern approaches for thermal analysis of electrical machines," IEEE Transactions on Industrial Electronics, vol. 56, no. 3, pp. 871-882, 2009.

[118] D. Arumugam, P. Logamani, and S. Karuppiah, "Electromagnetic \& thermal analysis of synchronous generator with different rotor structures for aircraft application," Alexandria Engineering Journal, vol. 57, no. 3, pp. 1447-1457, 2018.

[119] B. Adkins, W. Philipp, and A. Hossle, "Electrical machines for aircraft," Proceedings of the IEE Part A: Power Engineering, vol. 103, no. 1S, p. 116, 1956.

[120] A. El-Refaie and M. Osama, "High specific power electrical machines: a system perspective," CES Transactions on Electrical Machines and Systems, vol. 3, no. 1, pp. 88-93, 2019.

[121] R. Kasper and N. Borchardt, "Boosting power density of electric machines by combining two different winding types," IFAC-PapersOnLine, vol. 49, no. 21, pp. 322-329, 2016.

[122] "Hybrid-electric propulsion for regional aircraft," 2021, https://www.rolls-royce.com/innovation/propulsion/ regional-aircraft.aspx.

[123] W. R. Canders, J. Hoffmann, and M. Henke, "Cooling technologies for high power density electrical machines for aviation applications," Energies, vol. 12, no. 23, p. 4579, 2019.

[124] D. C. Deisenroth and M. Ohadi, "Thermal management of high-power density electric motors for electrification of aviation and beyond," Energies, vol. 12, no. 19, p. 3594, 2019.

[125] M. Lefik, K. Komeza, E. N. Juszczak et al., "High temperature machines: topologies and preliminary design," Open Physics, vol. 17, no. 1, pp. 657-669, 2019.

[126] J. Pyrhönen, T. Jokinen, and V. Hrabovcová, Design of Rotating Electrical Machines, John Wiley \& Sons, 2008.

[127] S. G. Burrow, P. H. Mellor, P. Churn, T. Sawata, and M. H. Holme, "Sensorless operation of a permanent-magnet generator for aircraft," IEEE Transactions on Industry Applications, vol. 44, no. 1, pp. 101-107, 2008.

[128] M. C. Kulan, N. J. Baker, and J. D. Widmer, "Design and analysis of compressed windings for a permanent magnet integrated starter generator," IEEE Transactions on Industry Applications, vol. 53, no. 4, pp. 3371-3378, 2017.

[129] J. Hong, L. Li, Z. Zong, and Z. Liu, "Current error vector based prediction control of the section winding permanent magnet linear synchronous motor," Energy Conversion and Management, vol. 52, no. 11, pp. 3347-3355, 2011.

[130] J. X. Wang, Y. Z. Li, S. N. Wang, H. S. Zhang, X. Ning, and W. Guo, "Experimental investigation of the thermal control effects of phase change material based packaging strategy for on-board permanent magnet synchronous motors," Energy Conversion and Management, vol. 123, pp. 232-242, 2016.

[131] A. Mohanty, M. Viswavandya, P. K. Ray, T. K. Panigrahi, and S. Mohanty, "Stability and optimisation of direct drive permanent magnet synchronous generator based tidal turbine," Vacuum, vol. 166, pp. 341-350, 2019.

[132] T. Feehally and J. M. Apsley, "The doubly fed induction machine as an aero generator," IEEE Transactions on Industry Applications, vol. 51, no. 4, pp. 3462-3471, 2015. 
[133] Y. Jia and K. Rajashekara, "Induction machine for more electric aircraft: enabling new electrical power system architectures," IEEE Electrification Magazine, vol. 5, no. 4, pp. 2537, 2017.

[134] Y. Jia and K. Rajashekara, "An induction generator-based AC/DC hybrid electric power generation system for more electric aircraft," IEEE Transactions on Industry Applications, vol. 53, no. 3, pp. 2485-2494, 2017.

[135] S. Mensou, A. Essadki, I. Minka, T. Nasser, and B. B. Idrissi, "Control and hardware simulation of a doubly fed induction aero-generator using dSPACE card," in 2019 International Conference of Computer Science and Renewable Energies (ICCSRE),, Agadir, Morocco, 2019.

[136] C. A. Ferreira, S. R. Jones, W. S. Heglund, and W. D. Jones, "Detailed design of a 30-kW switched reluctance starter/generator system for a gas turbine engine application," IEEE Transactions on Industry Applications, vol. 31, no. 3, pp. 553-561, 1995.

[137] P. H. Mellor, S. G. Burrow, T. Sawata, and M. Holme, "A wide-speed-range hybrid variable-reluctance/permanentmagnet generator for future embedded aircraft generation systems," IEEE Transactions on Industry Applications, vol. 41, no. 2, pp. 551-556, 2005.

[138] A. L. Rodrigues and A. J. Pires, "Reluctance machines incorporating high temperature superconducting materials on the rotor," Physica C: Superconductivity, vol. 470, no. 2, pp. 98$103,2010$.

[139] A. Siadatan, E. Afjei, H. Torkaman, and M. Rafie, "Design, simulation and experimental results for a novel type of twolayer 6/4 three-phase switched reluctance motor/generator," Energy Conversion and Management, vol. 71, pp. 199-207, 2013.

[140] M. Tursini, M. Villani, G. Fabri, and L. Di Leonardo, "A switched-reluctance motor for aerospace application: design, analysis and results," Electric Power Systems Research, vol. 142, pp. 74-83, 2017.

[141] S. Shoujun, L. Weiguo, D. Peitsch, and U. Schaefer, "Detailed design of a high speed switched reluctance starter/generator for more/all electric aircraft," Chinese Journal of Aeronautics, vol. 23, no. 2, pp. 216-226, 2010.

[142] J. Borg Bartolo, M. Degano, J. Espina, and C. Gerada, "Design and initial testing of a high-speed $45-\mathrm{kW}$ switched reluctance drive for aerospace application," IEEE Transactions on Industrial Electronics, vol. 64, no. 2, pp. 988-997, 2017.

[143] J. Faiz and K. Moayed-Zadeh, "Design of switched reluctance machine for starter/generator of hybrid electric vehicle," Electric Power Systems Research, vol. 75, no. 2-3, pp. 153-160, 2005.

[144] N. Jiao, W. Liu, T. Meng, J. Peng, and S. Mao, "Design and control of a two-phase brushless exciter for aircraft woundrotor synchronous starter/generator in the starting mode," IEEE Transactions on Power Electronics, vol. 31, no. 6, pp. 4452-4461, 2016.

[145] Z. Zhang, W. Liu, S. Mao et al., "Research on excitation control method for the three-phase brushless asynchronous excitation system of wound-field synchronous starter/generators," in 2017 IEEE Energy Conversion Congress and Exposition (ECCE),, pp. 2074-2078, Cincinnati, OH, USA, 2017.

[146] Z. Zhang, W. Liu, D. Zhao, S. Mao, T. Meng, and N. Jiao, "Steady-state performance evaluations of three-phase brushless asynchronous excitation system for aircraft starter/gen- erator," IET Electric Power Applications, vol. 10, no. 8, pp. 788-798, 2016.

[147] S. S. H. Bukhari, G. J. Sirewal, F. A. Chachar, and J. S. Ro, "Brushless field excitation scheme for wound field synchronous machines," Applied Sciences, vol. 10, no. 17, p. 5866, 2020.

[148] J. Vaidya and E. Gregory, "High speed induction generator for applications in aircraft power systems," in SAE Technical Paper Series, pp. 1830-1836, New York, USA, 2004.

[149] R. Bojoi, A. Cavagnino, A. Tenconi, and S. Vaschetto, "Control of shaft-line-embedded multiphase starter/generator for aero-engine," IEEE Transactions on Industrial Electronics, vol. 63, no. 1, pp. 641-652, 2016.

[150] E. Ganev, "Selecting the best electric machines for electrical power-generation systems: high-performance solutions for aerospace more electric architectures," IEEE Electrification Magazine, vol. 2, no. 4, pp. 13-22, 2014.

[151] C. Liu, K. T. Chau, J. Z. Jiang, X. Liu, and Z. Wang, "Design and control of a doubly-excited permanent-magnet brushless integrated-starter-generator for hybrid electric vehicles," in 2007 IEEE Industry Applications Annual Meeting, pp. 17021709, New Orleans, LA, USA, 2007.

[152] J.-C. MARÉ and F. U. Jian, "Review on signal-by-wire and power-by-wire actuation for more electric aircraft," Chinese Journal of Aeronautics, vol. 30, no. 3, pp. 857-870, 2017.

[153] J. Li, Z. Yu, Y. Huang, and Z. Li, “A review of electromechanical actuation system for more electric aircraft," in 2016 IEEE International Conference on Aircraft Utility Systems (AUS), pp. 490-497, Beijing, China, 2016.

[154] A. Emadi and M. Ehsani, "Aircraft power systems: technology, state of the art, and future trends," IEEE Aerospace and Electronic Systems Magazine, vol. 15, no. 1, pp. 28-32, 2000.

[155] G. Brando, A. Dannier, L. P. Di Noia, R. Rizzo, and S. I. Hamasaki, "Design of a PMSM for the electric steering of the nose landing gear," in 2016 International Symposium on Power Electronics, Electrical Drives, Automation and Motion (SPEEDAM), Capri, Italy, 2016.

[156] G. Brando, A. Dannier, A. Del Pizzo, and L. P. Di Noia, "Electric steering for aircraft nose landing gears using axial-flux permanent-magnet motors," in 2016 XXII International Conference on Electrical Machines (ICEM), Lausanne, Switzerland, 2016.

[157] F. Kelch, Y. Yang, B. Bilgin, and A. Emadi, "Investigation and design of an axial flux permanent magnet machine for a commercial midsize aircraft electric taxiing system," IET Electrical Systems in Transportation, vol. 8, no. 1, pp. 52-60, 2018.

[158] M. Lukic, A. Hebala, P. Giangrande et al., "State of the art of electric taxiing systems," in 2018 IEEE International Conference on Electrical Systems for Aircraft, Railway, Ship Propulsion and Road Vehicles \& International Transportation Electrification Conference (ESARS-ITEC), pp. 1-6, Nottingham, UK, 2018.

[159] N. Dzikus, J. Fuchte, A. Lau, and V. Gollnick, "Potential for fuel reduction through electric taxiing," in 11th AIAA Aviation Technology, Integration, and Operations (ATIO) Conference, p. 6931, Virginia Beach, USA, 2011.

[160] T. F. Johnson, "Electric green taxiing system (EGTS) for aircraft," IEEE Transactions on Transportation Electrification Web Portal, 2016.

[161] "Electric Taxiing Systems: Past, Present and the Possible Future,” January 2021, https://www.aviationtoday.com/ 
2019/05/01/electric-taxiing-systems-past-present-possiblefuture/.

[162] H. Xu, Y. Hu, and J. Yang, "Study on outer rotor FSCW permanent magnet machines for unmanned aerial vehicle electric green taxiing systems," in IOP Conference Series: Materials Science and Engineering, vol. 887, Chengdu, China, 2020no. 1, Article ID 012006.

[163] R. Wesche, "High-temperature superconductors," in Springer Handbook of Electronic and Photonic Materials, S. Kasap and P. Capper, Eds., Springer Handbooks. Springer, Cham, 2017.

[164] G. TURNEY, R. LUIDENS, K. Uherka, and J. Hull, "Aeronautical applications of high-temperature superconductors," Aircraft Design and Operations Meeting, p. 2142, 1989.

[165] P. J. Masson, D. S. Soban, E. Upton, J. E. Pienkos, and C. A. Luongo, "HTS motors in aircraft propulsion: design considerations," IEEE transactions on applied superconductivity, vol. 15, pp. 2218-2221, 2005.

[166] P. J. Masson and C. A. Luongo, "HTS machines for applications in all-electric aircraft," in 2007 IEEE Power Engineering Society General Meeting, Tampa, FL, USA, 2007.

[167] C. A. Luongo, P. J. Masson, T. Nam et al., "Next generation more-electric aircraft: a potential application for hts superconductors," IEEE Transactions on applied superconductivity, vol. 19, no. 3, pp. 1055-1068, 2009.

[168] F. Weng, M. Zhang, T. Lan, Y. Wang, and W. Yuan, "Fully superconducting machine for electric aircraft propulsion: study of AC loss for HTS stator," Superconductor Science and Technology, vol. 33, no. 10, article 104002, 2020.

[169] D. Dezhin, N. Ivanov, K. Kovalev, I. Kobzeva, and V. Semenihin, "System approach of usability of HTS electrical machines in future electric aircraft," IEEE Transactions on Applied Superconductivity, vol. 28, no. 4, pp. 1-5, 2018.

[170] M. Filipenko, L. Kühn, T. Gleixner et al., "Concept design of a high power superconducting generator for future hybridelectric aircraft," Superconductor Science and Technology, vol. 33, no. 5, article 054002, 2020.

[171] "With Ultralight Lithium-Sulfur Batteries, Electric Airplanes Could Finally Take Off," 2021, https://spectrum.ieee.org/ aerospace/aviation/with-ultralight-lithiumsulfur-batterieselectric-airplanes-could-finally-take-off.

[172] M. Tariq, A. I. Maswood, C. J. Gajanayake, and A. K. Gupta, "Aircraft batteries: current trend towards more electric aircraft," IET Electrical Systems in Transportation, vol. 7, no. 2, pp. 93-103, 2016.

[173] “The magic number that makes electric flight viable," 2021, https://www.flightglobal.com/business-aviation/the-magicnumber-that-makes-electric-flight-viable/140050.article.

[174] J. Kallo, G. Renouard-Vallet, M. Saballus, G. Schmithals, J. Schirmer, and K. A. Friedrich, "Fuel cell system development and testing for aircraft applications," in 18th world hydrogen energy conference 2010 - WHEC 16.-21, Essen, 2010.

[175] J. W. Pratt, L. E. Klebanoff, K. Munoz-Ramos, A. A. Akhil, D. B. Curgus, and B. L. Schenkman, "Proton exchange membrane fuel cells for electrical power generation on-board commercial airplanes," Applied Energy, vol. 101, pp. 776-796, 2013.

[176] K. Rajashekara, J. Grieve, and D. Daggett, "Hybrid fuel cell power in aircraft," IEEE Industry Applications Magazine, vol. 14, no. 4, pp. 54-60, 2008.

[177] K. Seeckt and D. Scholz, "Jet versus prop, hydrogen versus kerosene for a regional freighter aircraft," Deutscher Luftund Raumfahrtkongress, 2009.
[178] J.-M. Dilhac and M. Bafleur, "Energy harvesting in aeronautics for battery-free wireless sensor networks," Aerospace and Electronic Systems Magazine, vol. 29, no. 8, pp. 18-22, 2014.

[179] M. Pozzi, S. Guo, and M. Zhu, "Harvesting energy from the dynamic deformation of an aircraft wing under gust loading," in Health monitoring of structural and biological systems 2012, vol. 8348, article 834831, International Society for Optics and Photonics, 2012.

[180] S. Zelenika, Z. Hadas, S. Bader et al., "Energy harvesting technologies for structural health monitoring of airplane components-a review," Sensors, vol. 20, no. 22, p. 6685, 2020.

[181] Y. Shi, S. R. Hallett, and M. Zhu, "Energy harvesting behaviour for aircraft composites structures using macro-fibre composite: part I-integration and experiment," Composite Structures, vol. 160, pp. 1279-1286, 2017.

[182] H. Xie, Z. Huang, S. Guo, and E. Torru, "Feasibility of an electrostatic energy harvesting device for CFCs aircraft," Procedia Engineering, vol. 99, pp. 1213-1222, 2015.

[183] Z. Yang, W. Xu, and M. Shikh-Bahaei, "Energy efficient UAV communication with energy harvesting," IEEE Transactions on Vehicular Technology, vol. 69, no. 2, pp. 1913-1927, 2019.

[184] B. Ji, Z. Chen, Y. Li, S. Chen, G. Zheng, and H. Wen, "Energy harvesting and information transmission scheme with UAV relay cooperation," EURASIP Journal on Wireless Communications and Networking, vol. 2019, no. 1, 9 pages, 2019.

[185] V. Bonnin, E. Bénard, J. M. Moschetta, and C. A. Toomer, "Energy-harvesting mechanisms for UAV flight by dynamic soaring," International Journal of Micro Air Vehicles, vol. 7, no. 3, pp. 213-229, 2015.

[186] S. R. Anton and D. J. Inman, "Vibration energy harvesting for unmanned aerial vehicles," in Active and passive smart structures and integrated systems 2008, vol. 6928, article 692824, International Society for Optics and Photonics, 2008.

[187] Y. Liu, J. Deng, C. Liu, and S. Li, "Energy optimization analysis of the more electric aircraft," in , Article ID 012152IOP Conference Series: Earth and Environmental Science, vol. 113, Harbin, China, 2018.

[188] O. Zaporozhets, V. Isaienko, and K. Synylo, “Trends on current and forecasted aircraft hybrid electric architectures and their impact on environment," Energy, vol. 211, p. 118814, 2020. 